\title{
POSTHARVEST BEHAVIOR OF HIGHBUSH BLUEBERRY FRUITS CV. O’NEAL CULTIVATED WITH DIFFERENT ORGANIC FERTILIZATION TREATMENTS
}

\author{
Graciela Echeverría V. ${ }^{1}$, Juan Cañumir V. ${ }^{2 *}$ and Humberto Serri G. ${ }^{1}$
}

\begin{abstract}
Considering the increasing demand for organic products and the fact that Chile is far from export markets, fresh fruits of highbush blueberry (Vaccinium corymbosum L. $x$ Vaccinium darrowii Camp) from organic fertilization were stored at $3{ }^{\circ} \mathrm{C}$ and $90 \%$ RH for $30 \mathrm{~d}$ in modified atmosphere (MA) and conventional atmosphere (CA) with the objective of studying the effect of organic fertilization treatments in postharvest behavior. The variables, water content, weight loss, diameter loss, soluble solids, titratable acidity, $\mathrm{pH}$, and presence of pathogens were evaluated during three periods; with a divided plot factorial arrangement experimental design. Results were submitted to variance analysis, and Tukey test $(\mathrm{P} \leq 0.05)$ was applied when significant differences appeared. Most of the evaluated variables showed no differences between fruits treated with organic or conventional fertilization. Nevertheless, the greater presence of pathogens occurred in fruits treated with organic fertilization when they were stored in CA, being Botrytis cinerea the causal agent with greater incidence. The fruits stored in MA presented a better postharvest behavior than the fruits stored in CA, demonstrating less weight loss $(2.3 \%)$, diameter loss $(15.6 \%)$, incidence of microorganisms, less variation of soluble solids over time (14.6\%), acidity ( $0.37 \%$ citric acid), and humidity ( $81 \%)$.
\end{abstract}

Key words: organic fertilization, modified atmosphere, Botrytis, Vaccinium corymbosum.

\section{INTRODUCTION}

World blueberry consumption has risen mainly because of its health benefits (Sinelli et al., 2008), and organically produced blueberries are increasingly being consumed. Member countries of the European Union, as well as Japan, demonstrate an ever-increasing demand for organic products (Granatstein, 2000; Shea, 2004; Smith and Marsden, 2004; Sawyer et al., 2008). Almost all organic products are overpriced in relation to conventional products (ProChile, 2003; Kuepper and Diver, 2004).

The majority of blueberry orchards in Chile are conventionally managed with defined management guidelines (Hepp, 2005). However, management of organic blueberry orchards has not yet been defined. There are actually many questions about organic fertilization management because of the scarcity of

\footnotetext{
'Universidad de Concepción, Facultad de Agronomía, Av. Vicente Méndez 595, Casilla 537, Chillán, Chile.

${ }^{2}$ Universidad de Concepción, Facultad de Ingeniería Agrícola, Av. Vicente Méndez 595, Casilla 537, Chillán, Chile. *Corresponding author(jcanumir@udec.cl).

Received: 05 October 2007

Accepted: 08 April 2008.
}

supplies that comply with organic requirements (INN, 2004) and its efficiency in terms of production. At the same time, fertilization is one of the principal problems that producers face when changing from conventional to organic production (Morales, 2004). The basis of soil fertility management in organic systems consists in incorporating important quantities of organic matter $(\mathrm{OM})$ through the application of animal and plant origin materials that permit improving soil characteristics. The organic production system does not try to substitute the crop nutrient requirements with soluble fertilizers that inhibit microorganism activity, but aims to increment soil fertility and maintain it in the long-term. However, faced with nutritional deficiencies, it is possible to use several fertilizers of organic and mineral origin as a supplement (Céspedes et al., 2005). The fruits evaluated in this study came from plants treated with different sources of organic fertilization (Table 1) which are applied by organic blueberry producers in Chile.

Organic fertilization permits a balanced nutrient contribution; as a result, it is expected to obtain fruits with a similar or better quality than that produced with conventional fertilization.

Productive efforts to obtain quality fruit can be in 
vain if after harvest the fruit is not duly handled. This consideration is especially important for Chile since it is far from the markets where it exports fresh fruit, and which requires conservation in a bioclimatic chamber, as well as other techniques that permit maintaining quality. In postharvest the fruits respire at the expense of their nutritive reserves and transpire their own water content if there is no compensation of the respired substrates, initiating deterioration (Loyola et al., 1996; Romojaro et al., 1996; Wills et al., 1998; Cañumir and Loyola, 2004). Modified atmosphere is a fruit conservation method that reduces respiration rate and water loss of the product which implies the replacement of air in a container with a mixture of different gases, but without exerting subsequent control during storage. Usually, the concentration of $\mathrm{CO}_{2}$ and/or $\mathrm{N}$ is increased and $\mathrm{O}_{2}$ decreased (Romojaro et al., 1996; Catalá, 1998).

The objective of this study was to evaluate the effect of organic fertilization in postharvest of the blueberry fruits stored in modified and conventional atmospheres.

\section{MATERIALS AND METHODS}

\section{Raw material}

Southern highbush blueberry fruits ( $V$. corymbosum L. x $V$. darrowii Camp) cv. O'Neal were manually harvested on plants treated with distinct fertilization treatments from an orchard planted 2 years earlier, first harvest, located in the Nogal Experimental Station of the Universidad de Concepción, Chillán Campus (36 $59^{\circ}$ ' S; $\left.72^{\circ} 08^{\prime} \mathrm{W}\right)$. Treated plants were randomly distributed in the orchard with four replicates per fertilization treatment (Tables 1 and 2). However, harvest was carried out for each fertilization treatment from the total of replicates, considering that the second-year plants obtained low production $\left(<0.5 \mathrm{~kg} \mathrm{plant}^{-1}\right)$, especially those organically treated.

The fruits were selected by color $(>90 \%$ blue surface), rejecting those with low caliber $(<0.5 \mathrm{~cm})$, overripe and underripe, with microorganism development, soft and/ or split. The selected fruits were taken to the Postharvest Laboratory in the Pilot Plant of the Departamento de Agroindustrias of the Universidad de Concepción, Chillán Campus, where the assay was prepared for storage. The total of fruits from each fertilization treatment was divided in equal parts to be stored in a modified atmosphere (MA) and a conventional atmosphere (CA). In each storage atmosphere, the fruits from the distinct fertilization treatments (total of 13, Table 1) were divided into three replicates per treatment for each day of evaluation $(0,15$, and $30 \mathrm{~d}$ ), resulting in a total of 234 plastic pots (Clamshell Driscoll's $125 \mathrm{~g}$ capacity) in which the blueberry fruits were deposited.

\section{Experimental design}

The behavior of fruits from plants treated with 13 different fertilization treatments and stored in two atmospheric conditions (MA and $\mathrm{CA}$ ) in three storage periods corresponding to day 0,15 , and 30 were evaluated. A subdivided plot design with factorial arrangement $13 \times 2 \times 3$ was applied (Table 3 ) for the variables percentage humidity, soluble solids, titratable acidity, $\mathrm{pH}$, and percentage decay. A divided plot design with factorial arrangement $2 \times 13$ (Table 3) was also applied where the factors corresponded to the two atmospheric conditions (MA and CA), and fertilization type for the weight and equatorial diameter loss

Table 1. Fertilization treatments used in the blueberry orchard, first season. Chillán, Chile.

\begin{tabular}{|c|c|c|}
\hline $\mathbf{T}$ & Fertilization $^{1}$ & Postplantation dose ${ }^{1}$ \\
\hline $\mathrm{T} 1$ & Broiler bed 10 & $10 \mathrm{~m}^{3} \mathrm{ha}^{-1}$ \\
\hline $\mathrm{T} 2$ & Broiler bed 20 & $20 \mathrm{~m}^{3} \mathrm{ha}^{-1}$ \\
\hline $\mathrm{T} 3$ & Hog guano $10(\mathrm{HG})$ & $10 \mathrm{~m}^{3} \mathrm{ha}^{-1}$ \\
\hline $\mathrm{T} 4$ & Hog guano 20 & $20 \mathrm{~m}^{3} \mathrm{ha}^{-1}$ \\
\hline T5 & Fish filter & $10 \mathrm{~m}^{3} \mathrm{ha}^{-1}$ \\
\hline T6 & $\mathrm{HG}+$ Tea compost & $10 \mathrm{~m}^{3} \mathrm{ha}^{-1}+100 \mathrm{~L} \mathrm{ha}^{-1}$ irrig $^{-1}$ \\
\hline $\mathrm{T} 7$ & HG + Bioplasm & $10 \mathrm{~m}^{3} \mathrm{ha}^{-1}+20 \mathrm{~L} \mathrm{ha}^{-1}(6$ appl. $)$ \\
\hline $\mathrm{T} 8$ & $\mathrm{HG}+$ Supermagro & $10 \mathrm{~m}^{3} \mathrm{ha}^{-1}+100 \mathrm{~L} \mathrm{ha}^{-1}$ irrig $^{-1}$ \\
\hline T9 & $\mathrm{HG}+$ Fruticrop & $10 \mathrm{~m}^{3} \mathrm{ha}^{-1}+5 \mathrm{~L}$ ha-1 (5 appl.) \\
\hline $\mathrm{T} 10$ & HG + Oiko-Bac-Nitrobio & $10 \mathrm{~m}^{3} \mathrm{ha}^{-1}+1 \mathrm{~L} \mathrm{ha}^{-1}$ (2 appl.) \\
\hline T11 & HG + Fish oil & $10 \mathrm{~m}^{3} \mathrm{ha}^{-1}+1 \mathrm{~L} \mathrm{ha}^{-1}$ irrig $^{-1}$ \\
\hline $\mathrm{T} 12$ & Without fertilization & - \\
\hline $\mathrm{T} 13$ & Conventional fertilization & $55 \mathrm{~kg} \mathrm{ha}^{-1}$ (urea) \\
\hline
\end{tabular}

T: treatment; appl.: applications; irrig: irrigation.

${ }^{1}$ Dose frequently used by organic producers in Chile. 
Table 2. Description of organic fertilizers used.

\begin{tabular}{|c|c|}
\hline Organic fertillizer & Description \\
\hline Broiler bed & Droppings composted with sawdust. Estimated nutrient input: $1.40 \% \mathrm{~N}, 1.85 \% \mathrm{P}$, and $1.55 \% \mathrm{~K}$. \\
\hline Hog guano & Composted droppings. Estimated nutrient input: $0.80 \% \mathrm{~N}, 0.40 \% \mathrm{P}$, and $0.35 \% \mathrm{~K}$. \\
\hline Fish filter & $\begin{array}{l}\text { Subproduct of fish oil production, consistent with the solid surplus trapped in the filter. High } \\
\text { biological value. }\end{array}$ \\
\hline Tea compost & $\begin{array}{l}\text { Extract of compost fermented in water for } 7 \text { days. Its nutrient richness depends on compost } \\
\text { quality. }\end{array}$ \\
\hline Bioplasm & $\begin{array}{l}\text { Microalgae suspension }(F \text {. coronella }) \text {. Transform minerals into organic compounds } \\
\text { assimilable by plants that receive them in their vascular system through leaves or roots, } \\
\text { according to whether they were applied. Contains } 720 \mathrm{mg} \mathrm{L}^{-1} \mathrm{~N}, 240 \mathrm{mg} \mathrm{L}^{-1} \mathrm{P} \text {, and } 6.22 \mathrm{mg} \\
\mathrm{L}^{-1} \mathrm{~K} \text {. }\end{array}$ \\
\hline Supermagro & $\begin{array}{l}\text { Biofertilizer standardized by CET-Yumbel, consisting in a solution of guano, water, milk, } \\
\text { molasses, and minerals fermented for } 30 \text { to } 45 \text { days. }\end{array}$ \\
\hline Fruticrop & $\begin{array}{l}\text { Biostimulant base of macro and microelements, amino acids, carbohydrates, vitamins, and } \\
\text { phytohormones. Contains } 7.20 \% \mathrm{~N}, 3.60 \% \mathrm{P} \text {, and } 4.80 \% \mathrm{~K} \text {. }\end{array}$ \\
\hline Oiko-Bac-Nitrobio & $\begin{array}{l}\text { Biological fertilizer consisting of various strains of non symbiotic Azotobacter bacteria able } \\
\text { to fix } \mathrm{N} \text { atmospherically and make it available to be absorbed by the plant. }\end{array}$ \\
\hline Fish oil & $\begin{array}{l}\text { Product from pressed fish with a complex chemical composition that depends on the } \\
\text { structure of fat acids, which vary considerably depending on the species of fish and its food. }\end{array}$ \\
\hline
\end{tabular}

variables. Both variables were quantified with the percent difference between day 0 and 30 .

\section{Storage atmospheres}

Fruit storage in MA was carried out by packing the pots in colorless bags of selective permeability, 175 x 300 $\mathrm{mm}$ in size and $58 \mathrm{~mm}$ thick (model BB4L, Cryovac, New Jersey, USA). Before packing with a gas mixing machine (Witt model KM 100-3 MEM, Witten, Germany), a mixture of $4 \% \mathrm{O}_{2}, 10 \% \mathrm{CO}_{2}$, with the remaining $86 \%$ $\mathrm{N}$, and before emptying this gaseous mixture in the bag and sealing it, creates a vacuum in its interior to maintain the composition of the introduced gases. The bags were sealed with a sealing machine (Multivac model A 300/16, Wolfertschwenden, Germany). Fruit storage in CA contains the normal gas mixture making up the air of the Earth's atmosphere and composed of $78 \% \mathrm{~N}, 21 \% \mathrm{O}_{2}$, and $0.03 \% \mathrm{CO}_{2}$ (Wills et al., 1998). Storage temperature for both atmospheres was $3{ }^{\circ} \mathrm{C}$ and $90 \%$ relative humidity (RH).

\section{Variables evaluated}

Percentage humidity(\%HFMb). This was determined by a gravimetric method in three standard-sized fruits (14 $\mathrm{mm}$ equatorial diameter and $10 \mathrm{~mm}$ polar diameter) for each replicate of each fertilization treatment. Fruits were weighed before being put into a common drying oven (Weiss Gallenkamp 0VB-300-010N, Loughborough, UK), for $48 \mathrm{~h}$ at $70{ }^{\circ} \mathrm{C}$ and percentage humidity fresh matter basis $(\% \mathrm{HFMb})$ of the blueberries by weight differences on an analytical scale $\pm 0.01 \mathrm{~g}$ (Denver Instrument PK352, Denver, Colorado, USA).

Weight and equatorial diameter loss. These were determined for each fertilization treatment in three replicates, quantifying the difference with respect to weight and equatorial diameter between day 0 and 30 with an analytical balance $\pm 0.1 \mathrm{~g}$ (Denver Instrument PK-352, Arvada, Colorado, USA) and a digital calibrator (General Tools, 147, New York, USA) $\pm 001 \mathrm{~mm}$. The result was expressed as a percentage of the initial value.

Soluble solids (SS), pH, and titratable acidity. These were determined in the juice of the blueberry fruits for SS with a manual thermo-compensated refractometer (Sudelab RHB-40, Santiago, Chile) on each evaluation day, while $\mathrm{pH}$ was determined in $2 \mathrm{~g}$ of macerated fruits with a pH meter (Hanna Instruments Chile HI 8521, Santiago, Chile). Then each maceration was diluted in $75 \mathrm{~mL}$ distilled water with an agitator (Weiser Analitica, 752A, Santiago, Chile) and $\mathrm{pH}$ was adjusted to 8.1-8.2 by adding $\mathrm{NaOH} 0.01 \mathrm{~N}$. The result was expressed as a percentage of predominant citric acid.

Presence of pathogens. On each evaluation day, fruits with decay and presence of fungal mycelia were counted, taken to the phytopathology laboratory of the Facultad de Agronomía of the Universidad de Concepción to carry 
Table 3. Results of ANOVA for experimental design of plots divided with factorial arrangement $2 \times 3 \times 13$ and split plot experimental design with factorial arrangement $2 \times 13$. Period of 0-30 d.

\begin{tabular}{|c|c|c|c|c|c|c|c|}
\hline \multirow[b]{2}{*}{ Factors } & \multicolumn{7}{|c|}{ Dependent variables } \\
\hline & \%НFMb & $\% \mathrm{SS}$ & TA & pH & $\% P d$ & $\% \mathrm{Wl}$ & $\% \mathrm{DI}$ \\
\hline $\mathrm{A}$ & $*$ & $*$ & $*$ & ns & * & $*$ & * \\
\hline $\mathrm{D}$ & $*$ & $*$ & $*$ & $*$ & $*$ & na & na \\
\hline $\mathrm{T}$ & ns & $*$ & $*$ & $*$ & $*$ & ns & $*$ \\
\hline $\mathrm{A} \times \mathrm{T}$ & ns & ns & ns & ns & $*$ & ns & ns \\
\hline $\mathrm{D} \times \mathrm{T}$ & ns & $*$ & $*$ & $*$ & $*$ & na & na \\
\hline A x D & $*$ & $*$ & ns & ns & $*$ & na & na \\
\hline $\mathrm{A} \times \mathrm{D} \times \mathrm{T}$ & ns & ns & ns & ns & $*$ & na & na \\
\hline
\end{tabular}

*P $\leq$ 0.05. \%HFMb: percentage of humidity fresh matter basis; \%SS: percentage of soluble solids; TA: titratable acidity; \%Pd: percentage decay; \%Wl: percentage weight lost; \%Dl: percentage diameter lost; ns: not significant ( $\mathrm{p}>0.05)$; na: not applicable to experimental design.

A: storage atmosphere; D: days of storage; T: fertilization treatment.

out pathogen culture and identification. The result was expressed as a percentage of the total fruits in each plastic container.

\section{Statistical analysis}

Angular transformation was applied to the results expressed as a percentage to normalize the data (Little and Hills, 1978). Analysis of variance was conducted with Statistica 6.0 (StatSoft, 1996) software at 95\% confidence level and the Tukey test $(\mathrm{P} \leq 0.05)$ was applied when significant differences arose.

\section{RESULTS AND DISCUSSION}

Percentage humidity (\%HFMb). No significant differences were found among fertilization treatments in the evaluation of this variable which averaged $81 \% \mathrm{HFMb}$. Furthermore, fertilization did not interact with the other factors under study (Table 3). Therefore, the fertilization source was not important in the postharvest of the stored fruits for this variable. Atmospheric factors and days in storage showed significant differences and interaction (Table 4).

Fruits stored in MA lost $4.2 \%$ humidity at the end of the assay compared to the initial value, while those stored in CA lost 8.6\%. The first result coincides with what Loyola et al. (1996) found in highbush blueberry 'Blueray' stored for $28 \mathrm{~d}$ in $\mathrm{MA}$ at $0{ }^{\circ} \mathrm{C}$, obtaining a $7 \%$ loss after storing fruits of highbush and rabbiteye blueberries for $2 \mathrm{wk}$ at $7.2^{\circ} \mathrm{C}$.

The greater humidity content in the fruits stored in MA was due to water loss altered by the selective plastic permeability films used to store the fruits, and there was greater resistance exerted and increasing relative humidity inside the bags (Loyola et al., 1996; Navarrete, 2004). Furthermore, a microatmosphere is produced inside the bags, low in $\mathrm{O}_{2}$ and high in $\mathrm{CO}_{2}$, reducing the respiration rate, and thus water loss, since enzymes participating in glycolysis are inhibited (Watkins y Zhang, 1998).

Soluble solids $(\% \mathrm{SS})$. Significant differences were observed in the three factors under study and interaction between days of storage and fertilization treatment, as well as between storage atmosphere and days in storage (Table 3).

Fruits stored in MA did not show significant differences in SS over time, with a mean value of $14.6 \%$. On the contrary, fruits stored in CA showed significant differences with an increase in SS from 14.6 to $16.7 \%$ (Table 4).

The increase in SS over time coincides with what Miller (1988) informed in rabbiteye blueberry, Bounous et al. (1997) in highbush blueberry, and Hevia et al. (2000) in red currant (Ribes rubrum L.). SSs increased over time due to fruit dehydration. Loyola et al. (1993) state that if greater water loss occurs then the effect is a concentration of SSs. The fruits stored in CA were statistically different than those stored in MA showing greater SS contents starting on storage day 15. MA decreases fruit dehydration by exerting greater resistance to water loss (Loyola et al., 1996). This influence of MA on the lower stored fruit dehydration coincides with that observed in the SS variable previously evaluated.

There were no differences between fruits from organic fertilization treatments and fruits from conventional fertilization (T13) maintained over time (Table 5). SSs probably decreased due to the consumption of the fruit soluble sugars, but their water loss proved to have a greater sugar concentration, therefore SSs increased. However, these two effects are opposed so that SSs tend to be maintained over time (Navarrete, 2004).

Titratable acidity. Significant differences were observed in the three factors under study and interaction between days of storage and type of fertilization (Table 3 ). 
Table 4. Percentage humidity and soluble solids (SS) of blueberries for different types of atmosphere and days of storage.

\begin{tabular}{|c|c|c|c|c|c|c|c|c|}
\hline \multirow[b]{3}{*}{ TA } & \multicolumn{8}{|c|}{ Storage period } \\
\hline & \multicolumn{2}{|c|}{ Day 0} & \multicolumn{2}{|c|}{ Day 15} & \multicolumn{2}{|c|}{ Day 30} & \multicolumn{2}{|c|}{ Mean } \\
\hline & $\% H F M b$ & $\% \mathrm{SS}$ & $\%$ HFMb & $\%$ SS & $\%$ HFMb & $\% \mathrm{SS}$ & $\%$ \%FMb & $\% \mathrm{SS}$ \\
\hline MA & $83.4 \mathrm{aA}$ & $14.7 \mathrm{aA}$ & $82.1 \mathrm{aAB}$ & $14.2 \mathrm{aA}$ & $79.9 \mathrm{aB}$ & $14.8 \mathrm{aA}$ & 81.8 & 14.6 \\
\hline $\mathrm{CA}$ & $83.3 \mathrm{aA}$ & $14.7 \mathrm{aA}$ & $82.0 \mathrm{aA}$ & $15.5 \mathrm{bA}$ & $76.1 \mathrm{bB}$ & $16.7 \mathrm{bB}$ & 80.5 & 15.6 \\
\hline
\end{tabular}

TA: type of atmosphere; MA: modified atmosphere; CA: conventional atmosphere.

Capital letters horizontally different indicate differences between days of storage for the same atmosphere, and lower case letters vertically different indicate differences between types of atmospheres for the same storage day, according to Tukey test $(\mathrm{P} \leq 0.05)$.

The fruits stored in CA showed greater titratable acidity $(0.41 \%$ predominant citric acid) than those stored in MA $(0.37 \%$ predominant citric acid). This result is an effect of the greater dehydration of the fruits stored in CA, as was observed in the above-mentioned percentage humidity and SS variables. The same as for SS, fruit dehydration provokes an acid concentration, and consequently shows a greater value in MA.

Acidity of most fruits from organic fertilization treatments was maintained over time, the same as those with conventional fertilization (T13). Only the organic treatments $\mathrm{T} 7$ and $\mathrm{T} 11$ varied in acid content over time up to storage day 30 , with an acidity increase of $0.32 \%$ to $0.56 \%$, and $0.26 \%$ to $0.44 \%$, respectively (Table 5 ).

Citric acid is the principal organic acid of the blueberry; therefore titratable acidity is attributable to a great extent to its presence (Wiley, 1997; Hevia et al., 2000; Gil, 2004). Acids are one of the energy reserves of the fruit; therefore these are used in the respiration process and converted to more simple molecules such as $\mathrm{CO}_{2}$ and water (Wills et al., 1998). As a result of respiration, acids decrease, but water loss in the fruit increases its concentration. As a consequence, titratable acidity tended to be maintained over time in most of the fertilization treatments. In other assays, an increase in acidity over time was observed, with values greater than those of the assay. Thus, in rabbiteye blueberry 'Woodard', Smittle and Miller (1988) found an increase in acidity over time of $0.52 \%$ to $0.63 \%$ in 21 days of storage at $5{ }^{\circ} \mathrm{C}$. On the other hand, Loyola et al. (1996) found an increase in acidity starting on storage day 7 at $0{ }^{\circ} \mathrm{C}$, with values varying from $0.64 \%$ to $0.85 \%$ in highbush blueberry 'Blueray'.

Table 5. Percentages of soluble solids (\%SS) and citric acid (\%Ac), and pH of blueberries for different fertilizer treatments and days of storage.

\begin{tabular}{|c|c|c|c|c|c|c|c|c|c|}
\hline \multirow[b]{2}{*}{$\mathbf{T}$} & \multicolumn{3}{|c|}{ Day 0} & \multicolumn{3}{|c|}{ Day 15} & \multicolumn{3}{|c|}{ Day 30} \\
\hline & $\% \mathrm{SS}$ & $\%$ Ac & pH & $\% \mathrm{SS}$ & $\%$ Ac & pH & $\% \mathrm{SS}$ & $\%$ Ac & pH \\
\hline $\mathrm{T} 1$ & $15.1 \mathrm{abA}$ & $0.27 \mathrm{aA}$ & 4.27abA & $14.7 \mathrm{aA}$ & $0.32 \mathrm{aA}$ & 4.09abA & $15.8 \mathrm{abA}$ & $0.38 \mathrm{bA}$ & $4.15 \mathrm{aA}$ \\
\hline $\mathrm{T} 2$ & $14.7 \mathrm{abA}$ & $0.36 \mathrm{aA}$ & 4.13abcdA & $15.7 \mathrm{aA}$ & $0.32 \mathrm{aA}$ & $4.22 \mathrm{aA}$ & 17.2abA & $0.42 \mathrm{abA}$ & $4.06 \mathrm{aA}$ \\
\hline $\mathrm{T} 3$ & $16.4 \mathrm{abA}$ & $0.43 \mathrm{aA}$ & $3.71 \mathrm{dA}$ & $14.0 \mathrm{aA}$ & $0.40 \mathrm{aA}$ & 3.79abA & 15.0abA & $0.44 \mathrm{abA}$ & $3.85 \mathrm{abA}$ \\
\hline $\mathrm{T} 4$ & $12.4 \mathrm{bA}$ & $0.39 \mathrm{aA}$ & $3.69 \mathrm{dA}$ & $14.9 \mathrm{aA}$ & $0.40 \mathrm{aA}$ & $3.69 \mathrm{bA}$ & $15.0 \mathrm{abA}$ & $0.50 \mathrm{abA}$ & $3.51 \mathrm{bA}$ \\
\hline $\mathrm{T} 5$ & $15.0 \mathrm{abA}$ & $0.36 \mathrm{aA}$ & $3.77 \mathrm{cdA}$ & $13.8 \mathrm{aA}$ & $0.50 \mathrm{aA}$ & $3.64 \mathrm{bA}$ & $15.2 \mathrm{abA}$ & $0.49 \mathrm{abA}$ & $3.72 \mathrm{abA}$ \\
\hline T6 & $17.3 \mathrm{aA}$ & $0.39 \mathrm{aA}$ & $3.74 \mathrm{cdA}$ & $15.5 \mathrm{aA}$ & $0.38 \mathrm{aA}$ & 3.81abA & $16.2 \mathrm{abA}$ & $0.40 \mathrm{abA}$ & 3.79abA \\
\hline $\mathrm{T} 7$ & $16.5 \mathrm{abA}$ & $0.32 \mathrm{aA}$ & $4.17 \mathrm{abcA}$ & $15.1 \mathrm{aA}$ & $0.40 \mathrm{aAB}$ & 3.86abAB & $14.9 \mathrm{abA}$ & $0.56 \mathrm{aB}$ & 3.68abB \\
\hline T8 & $13.7 \mathrm{abA}$ & $0.32 \mathrm{aA}$ & $3.94 \mathrm{bcdA}$ & $14.8 \mathrm{aA}$ & $0.36 \mathrm{aA}$ & 3.89abA & $16.4 \mathrm{abA}$ & $0.48 \mathrm{abA}$ & $3.80 \mathrm{abA}$ \\
\hline Т9 & $13.3 \mathrm{abA}$ & $0.30 \mathrm{aA}$ & $4.25 \mathrm{abA}$ & $14.5 \mathrm{aA}$ & $0.38 \mathrm{aA}$ & $3.90 \mathrm{abA}$ & $17.6 \mathrm{aA}$ & $0.34 \mathrm{bA}$ & $3.92 \mathrm{abA}$ \\
\hline $\mathrm{T} 10$ & $13.1 \mathrm{abA}$ & $0.29 \mathrm{aA}$ & 4.10abcdA & $13.8 \mathrm{aA}$ & $0.43 \mathrm{aA}$ & $3.76 \mathrm{bA}$ & $12.8 \mathrm{bA}$ & $0.43 \mathrm{abA}$ & $3.85 \mathrm{abA}$ \\
\hline T11 & $15.5 \mathrm{abA}$ & $0.26 \mathrm{aA}$ & $4.40 \mathrm{aA}$ & $14.8 \mathrm{aA}$ & $0.38 \mathrm{aAB}$ & 3.84abB & 16.7abA & $0.44 \mathrm{abB}$ & $3.78 \mathrm{abB}$ \\
\hline $\mathrm{T} 12$ & $13.3 \mathrm{abA}$ & $0.34 \mathrm{aA}$ & $4.40 \mathrm{aA}$ & $16.2 \mathrm{aA}$ & $0.38 \mathrm{aA}$ & 3.89abB & $16.2 \mathrm{abA}$ & $0.37 \mathrm{bA}$ & $3.88 \mathrm{abB}$ \\
\hline $\mathrm{T} 13$ & $14.4 \mathrm{abA}$ & $0.40 \mathrm{aA}$ & $4.23 \mathrm{abA}$ & $14.7 \mathrm{aA}$ & $0.41 \mathrm{aA}$ & $3.81 \mathrm{abA}$ & $16.0 \mathrm{abA}$ & $0.43 \mathrm{abA}$ & 3.81abA \\
\hline
\end{tabular}

T: fertilization treatment; T1: broiler bed 10; T2: broiler bed 20; T3: hog guano 10 (HG); T4: hog guano 20; T5: fish filter; T6: HG + tea compost; T7: HG + Bioplasm; T8: HG + Supermagro; T9: HG + Fruticrop; T10: HG + Oiko-Bac-Nitrobio; T11: HG + fish oil; T12: without fertilization; T13: conventional fertilization (urea).

Capital letters horizontally different indicate differences between storage day for the same fertilization treatment and lower case letters vertically different indicate differences between fertilization treatments for the same storage day, according to Tukey test $(\mathrm{P} \leq 0.05)$ 
Table 6. Weight and equatorial diameter loss in blueberry fruits for different storage atmospheres and fertilization treatments between 0-30 days of storage.

\begin{tabular}{|c|c|c|c|c|c|}
\hline \multirow[b]{2}{*}{$\mathbf{T}$} & \multirow[b]{2}{*}{ Fertilization } & \multicolumn{2}{|c|}{ Weight } & \multicolumn{2}{|c|}{ Diameter $^{1}$} \\
\hline & & MA & $\mathbf{C A}$ & MA & $\mathbf{C A}$ \\
\hline & & & & 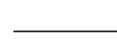 & \\
\hline $\mathrm{T} 1$ & Broiler bed 10 & $1.3 \mathrm{aA}$ & $9.9 \mathrm{aB}$ & & \\
\hline $\mathrm{T} 2$ & Broiler bed 20 & $3.0 \mathrm{aA}$ & $12.0 \mathrm{aB}$ & & \\
\hline $\mathrm{T} 3$ & Hog guano10 (HG) & $1.9 \mathrm{aA}$ & $12.3 \mathrm{aB}$ & & \\
\hline $\mathrm{T} 4$ & Hog guano 20 & $3.0 \mathrm{aA}$ & $10.9 \mathrm{aB}$ & & \\
\hline T5 & Fish filter & $1.9 \mathrm{aA}$ & $11.2 \mathrm{aB}$ & & \\
\hline T6 & $\mathrm{HG}+$ Tea compost & $2.5 \mathrm{aA}$ & $9.1 \mathrm{aB}$ & & \\
\hline $\mathrm{T} 7$ & HG + Bioplasm & $2.8 \mathrm{aA}$ & $12.3 \mathrm{aB}$ & & \\
\hline $\mathrm{T} 8$ & $\mathrm{HG}+$ Supermagro & $2.0 \mathrm{aA}$ & $11.1 \mathrm{aB}$ & & \\
\hline T9 & HG + Fruticrop & $2.8 \mathrm{aA}$ & $10.4 \mathrm{aB}$ & & \\
\hline $\mathrm{T} 10$ & HG + Oiko-Bac-Nitrobio & $1.7 \mathrm{aA}$ & $9.8 \mathrm{aB}$ & & \\
\hline $\mathrm{T} 11$ & $\mathrm{HG}+$ Fish oil & $2.0 \mathrm{aA}$ & $12.6 \mathrm{aB}$ & & \\
\hline $\mathrm{T} 12$ & Without fertilization & $1.7 \mathrm{aA}$ & $11.7 \mathrm{aB}$ & & \\
\hline $\mathrm{T} 13$ & Conventional fertilization (urea) & $3.1 \mathrm{aA}$ & $11.1 \mathrm{aB}$ & & \\
\hline Mean & & $2.3 \mathrm{~A}$ & $11.0 \mathrm{~B}$ & $15.6 \mathrm{~A}$ & $18.2 \mathrm{~B}$ \\
\hline
\end{tabular}

${ }^{1}$ Mean of the storage atmospheres.

T: fertilization treatment; MA: modified atmosphere; CA: conventional atmosphere.

Capital letters horizontally different indicate differences between storage atmospheres and lower case letters vertically different indicate significant differences between fertilization treatments, according to Tukey test $(\mathrm{P} \leq 0.05)$.

pH. Significant differences and interaction were observed between fertilization and days of storage factors (Table 3). In most fruits from organic fertilization treatments, $\mathrm{pH}$ was maintained over time, the same as for the fruits from conventional fertilization (T13), with the exception of T7, T11, and T12 that showed significant differences due to a decrease in $\mathrm{pH}$ over time (Table 5). The tendency of $\mathrm{pH}$ decreasing over time coincides with results found by Navarrete (2004) for rabbiteye 'Bonita' blueberry and results by Smittle and Miller (1988) for rabbiteye blueberry 'Climax' and 'Woodard'. Diffusion of $\mathrm{CO}_{2}$ in the tissues of the fruit will decrease $\mathrm{pH}$ according to Navarrete (2004).

The $\mathrm{CO}_{2}$ released in the metabolic processes of the cell reacts with water forming carbonic acid which is unstable and dissociates releasing $\mathrm{H}^{+}$and $\mathrm{HCO}_{3}^{-}$(Cabezas, 2004). The free protons would explain the $\mathrm{pH}$ decrease whereas $\mathrm{HCO}_{3}{ }^{-}$would explain titratable acidity increase.

At the start of the assay, the greatest difference in $\mathrm{pH}$ observed was between the fruits from the distinct fertilization treatments, being significant differences between some fruits from organic fertilization treatments with respect to those with conventional fertilization. As storage time increased there were fewer differences between fertilization treatments in relation to $\mathrm{pH}$ (Table 5). Therefore, the effect on $\mathrm{pH}$ of fertilization treatments of stored fruits decreased over storage time.
Inferior $\mathrm{pH}$ values have been reported in highbush blueberry by Makus and Morris (1987) with a pH of 3.14, and by Loyola et al. (1993) in highbush blueberry 'Bluecrop' and 'Blueray' with $\mathrm{pH} 3.45$ and 3.57, respectively.

Weight loss (\%). In this variable, there was no interaction between factors and significant differences were found only in the storage atmosphere factor (Table 3). Fruits from organic fertilization treatments behaved in the same way as fruits from conventional fertilization (T13) in both storage atmospheres. However, each treatment behaved in a distinct way when stored in each atmosphere (Table 6).

Fruits stored in MA demonstrated the lowest weight losses $(2.3 \%$ mean), showing significant differences with the fruits stored in CA with the most weight loss $(11.0 \%$ mean). The greatest weight loss in fruits stored in CA coincided with that observed by Navarrete (2004) in rabbiteye blueberry 'Bonita' and by Bounous et al. (1997) in highbush blueberry 'Dixi', 'Coville', and 'Darrow'.

Fruits weight loss is mainly due to water loss which is produced by a difference in vapor pressure between the fruits and surrounding air. This loss is affected by the area/ volume relationship, mechanical wounds on the epidermis area, the nature of the bag area, and storage temperature (Wills et al., 1998). Small-sized fruits such as blueberries show a high area/volume, therefore dehydrate more than 
Table 7. Percentage of blueberry fruit decay for different fertilizer treatments, atmosphere types, and days of storage.

\begin{tabular}{|c|c|c|c|c|c|c|c|}
\hline \multirow[b]{2}{*}{$\mathbf{T}$} & \multirow[b]{2}{*}{ Fertilization } & \multicolumn{3}{|c|}{ Modified atmosphere } & \multicolumn{3}{|c|}{ Conventional atmosphere } \\
\hline & & Day 0 & Day 15 & Day 30 & Day 0 & Day 15 & Day 30 \\
\hline & & & & & 0 & & \\
\hline $\mathrm{T} 1$ & Broiler bed 10 & $0.0 \mathrm{aA}$ & $9.0 \mathrm{aB}+$ & $0.0 \mathrm{bA}+$ & $0.0 \mathrm{aA}$ & $0.0 \mathrm{cA}+$ & $45.3 \mathrm{abB}+$ \\
\hline $\mathrm{T} 2$ & Broiler bed 20 & $0.0 \mathrm{aA}$ & $2.0 \mathrm{abA}+$ & 8.3abA & $0.0 \mathrm{aA}$ & $28.3 \mathrm{abB}+$ & $0.0 \mathrm{cA}$ \\
\hline $\mathrm{T} 3$ & Hog guano10 (HG) & $0.0 \mathrm{aA}$ & $0.0 \mathrm{bA}$ & $0.0 \mathrm{bA}+$ & $0.0 \mathrm{aA}$ & $0.0 \mathrm{cA}$ & $43.0 \mathrm{abB}+$ \\
\hline $\mathrm{T} 4$ & Hog guano 20 & $0.0 \mathrm{aA}$ & $0.0 \mathrm{bA}+$ & $0.0 \mathrm{bA}+$ & $0.0 \mathrm{aA}$ & $31.3 \mathrm{aB}+$ & $43.7 \mathrm{abC}+$ \\
\hline $\mathrm{T} 5$ & Fish filter & $0.0 \mathrm{aA}$ & $0.0 \mathrm{bA}$ & $0.0 \mathrm{bA}$ & $0.0 \mathrm{aA}$ & $0.0 \mathrm{cA}$ & $0.0 \mathrm{cA}$ \\
\hline $\mathrm{T} 6$ & HG + Tea compost & $0.0 \mathrm{aA}$ & $0.0 \mathrm{bA}$ & $0.0 \mathrm{bA}$ & $0.0 \mathrm{aA}$ & $0.0 \mathrm{cA}$ & $0.0 \mathrm{cA}$ \\
\hline $\mathrm{T} 7$ & HG + Bioplasm & $0.0 \mathrm{aA}$ & $0.0 \mathrm{bA}$ & $0.0 \mathrm{bA}+$ & $0.0 \mathrm{aA}$ & $0.0 \mathrm{cA}$ & $37.0 \mathrm{bB}+$ \\
\hline $\mathrm{T} 8$ & $\mathrm{HG}+$ Supermagro & $0.0 \mathrm{aA}$ & $0.0 \mathrm{bA}$ & $0.0 \mathrm{bA}$ & $0.0 \mathrm{aA}$ & $0.0 \mathrm{cA}$ & $0.0 \mathrm{cA}$ \\
\hline T9 & HG + Fruticrop & $0.0 \mathrm{aA}$ & $0.0 \mathrm{bA}+$ & $2.7 \mathrm{bA}$ & $0.0 \mathrm{aA}$ & $27.7 \mathrm{abB}+$ & $0.0 \mathrm{cA}$ \\
\hline $\mathrm{T} 10$ & HG + Oiko-Bac-Nitrobio & $0.0 \mathrm{aA}$ & $0.0 \mathrm{bA}+$ & $0.0 \mathrm{bA}+$ & $0.0 \mathrm{aA}$ & $20.7 \mathrm{bB}+$ & $49.0 \mathrm{aC}+$ \\
\hline $\mathrm{T} 11$ & $\mathrm{HG}+$ Fish oil & $0.0 \mathrm{aA}$ & $0.0 \mathrm{bA}$ & $0.0 \mathrm{bA}$ & $0.0 \mathrm{aA}$ & $0.0 \mathrm{cA}$ & $0.0 \mathrm{cA}$ \\
\hline $\mathrm{T} 12$ & Without fertilization & $0.0 \mathrm{aA}$ & $0.0 \mathrm{bA}$ & $13.7 \mathrm{aB}+$ & $0.0 \mathrm{aA}$ & $0.0 \mathrm{cA}$ & $0.0 \mathrm{cA}+$ \\
\hline $\mathrm{T} 13$ & Conventional fertilization (urea) & $0.0 \mathrm{aA}$ & $0.0 \mathrm{bA}$ & $0.0 \mathrm{bA}$ & $0.0 \mathrm{aA}$ & $0.0 \mathrm{cA}$ & $0.0 \mathrm{cA}$ \\
\hline
\end{tabular}

T: fertilization treatment.

Capital letters horizontally different indicate differences between days of storage for the same treatment and type of atmosphere, while lower case letters vertically different indicate differences between treatments for the same day of storage and type of atmosphere, according to Tukey test (P $\leq 0.05)$.

The + sign horizontally indicates differences between types of atmospheres for the same treatment and day of storage, according to Tukey test $(\mathrm{P} \leq 0.05)$.

larger-sized fruits since they have a greater area to then have a waterproof and vapor proof waxy covering (bloom) which influences weight loss, restricting water loss by evaporation (Wills et al., 1998; Cabezas, 2004; Navarrete, 2004). The fruit peduncular scar should be small and dry after being harvested given that it is a source of fruit water loss (Makus and Morris, 1987; Buzeta, 1997).

Loss of equatorial diameter (\%). Significant differences were observed in the storage atmosphere and fertilization factors, but no interaction was shown between them (Table 3).

Fruits stored in CA showed a greater equatorial diameter loss (18.2\% mean), differing from fruits stored in MA which showed the lowest equatorial diameter loss (15.6\% mean) (Table 6). Also observed in the previous parameters was an effect of MA on stored fruits showing lower losses of initial characteristics. As it was already mentioned, MA exerts resistance to water and shows a greater $\mathrm{CO}_{2}$ content than $\mathrm{CA}$ which would have inhibited dehydration and degradation of pectic substances in the stored fruits, conserving their shape, therefore, their size (Cabezas, 2004; Navarrete, 2004).

Most of the fruits from organic fertilization treatments had the same diameter as fruits from conventional fertilization (T13), except for T6 and T9 which showed the greatest diameter reductions (Table 6).

After harvesting, the size of the fruits can be altered by water content which is maintained by osmotic forces inside the cells, by the degradation of pectic substances that weaken the cell walls, and by the cohesive forces that maintain the union between cells (Wills et al., 1998). As a consequence, the fruits are not able to maintain their shape and integrity (Cabezas, 2004).

Presence of pathogens. The three factors showed differences and interactions (Table 3 ). The presence of pathogens was expressed as a percentage of decayed fruits. The greatest percentage of decay was in the fruits stored in CA up to storage day 30 (Table 7), while the fruits stored in MA showed low decay percentages in contrast with those stored in CA, coinciding with that observed by Cabezas (2004) in raspberry (Rubus idaeus L.), and by Ceponis and Cappellini (1985) in highbush blueberry. Ceponis and Cappellini (1985) point out that the bag in MA increases the $\mathrm{CO}_{2}$ concentration in respiration, thus decreasing decay. According to Romojaro et al. (1996) and Wills et al. (1998), an atmosphere with $10 \%$ or more $\mathrm{CO}_{2}$ slows spore germination and fungal mycelia development.

Decay in this assay was caused by Botrytis cinerea, Alternaria sp. and Cladosporium sp. However, the pathogen with the greatest incidence was $B$. cinerea which infected flowers, small branches, and fruits in high humidity (over 95\%) conditions and with moderate temperatures between $15-20{ }^{\circ} \mathrm{C}$ (Gough, 1994). The 
presence of this fungus coincides with that observed by Navarrete (2004) in rabbiteye blueberry 'Bonita', and Hevia et al. (2000) in red currant. The incidence of Alternaria sp. and Cladosporium sp. coincides with the results by Loyola et al. (1993) in highbush blueberry 'Blueray', and results by Loyola and Andrade (1993) in highbush blueberry 'Elliott'.

In general, fruits from organic fertilization treatments tended to show decay, except for T5, T6, T8, and T11 which behaved in the same way as fruits from conventional fertilization (T13), without showing decay over time and in none of the storage atmospheres (Table 7).

\section{CONCLUSIONS}

In most of the variables evaluated, there were no differences in the postharvest behavior between fruits from organic fertilization and those from conventional fertilization.

The greatest presence of pathogens occurred in the fruits from organic fertilization treatments when stored in CA, being Botrytis cinerea the causal agent with the greatest incidence.

Fruits stored in MA showed a better postharvest behavior than those stored in CA, showing lower weight and diameter losses, lower microorganism incidence, and a lower variation over time of soluble solids, acidity, and humidity.

\section{RESUMEN}

Comportamiento en poscosecha de frutos de arándano cv. O'Neal cultivados con distintos tratamientos de fertilización orgánica. Considerando que la demanda por productos orgánicos es cada día mayor y que Chile se encuentra alejado de los mercados de exportación de fruta fresca, frutos de arándano alto (Vaccinium corymbosum L. x Vaccinium darrowii Camp) provenientes de fertilización orgánica fueron almacenados a $3{ }^{\circ} \mathrm{C}$ y 90\% HR durante 30 días, en atmósfera modificada (MA) y atmósfera convencional (CA) con el objetivo de estudiar el efecto de la fertilización orgánica en el comportamiento en poscosecha. En tres períodos se evaluaron contenido de humedad, pérdida de peso, pérdida de diámetro, sólidos solubles, acidez titulable, $\mathrm{pH}, \mathrm{y}$ presencia de patógenos. El diseño experimental fue de parcelas divididas con arreglo factorial. Los resultados fueron sometidos a un análisis de varianza y se aplicó test de Tukey $(\mathrm{P} \leq 0,05)$ cuando se presentaron diferencias significativas. En la mayoría de las variables evaluadas no hubo diferencias en el comportamiento en poscosecha entre los frutos provenientes de fertilización orgánica y de fertilización convencional. Sin embargo, la mayor presencia de patógenos ocurrió en los frutos provenientes de fertilizaciones orgánicas cuando fueron almacenados en CA, siendo Botrytis cinerea el agente causal de mayor incidencia. Los frutos almacenados en MA presentaron un mejor comportamiento en poscosecha que los almacenados en CA, es decir presentaron menores pérdidas de peso $(2,3 \%)$, pérdida de diámetro $(15,6 \%) \mathrm{e}$ incidencia de microorganismos, y una menor variación en el tiempo de sólidos solubles $(14,6 \%)$, acidez $(0,37 \%$ ácido cítrico) y humedad (81\%).

Palabras clave: fertilización orgánica, atmósfera modificada, Botrytis, Vaccinium corymbosum.

\section{LITERATURE CITED}

Bounous, G., G. Giacalone, A. Guarinoni, and C. Peano. 1997. Modified atmosphere storage of highbush blueberry. Acta Hort. (ISHS) 446:197-203.

Buzeta, A. 1997. Arándano. p. 52-89. In A. Buzeta (ed.) Chile: Berries para el 2000. Fundación Chile, Santiago, Chile.

Cabezas, P. 2004. Calidad de frambuesa (Rubus idaeus L.) cv. Tulameen almacenada en atmósfera modificada. Tesis de Ingeniero Agrónomo. Universidad de Concepción, Facultad de Agronomía, Chillán, Chile.

Cañumir, A., y C. Loyola. 2004. Manejo poscosecha de frutas y hortalizas. Universidad de Concepción, Facultad de Ingeniería Agrícola, Departamento de Agroindustrias, Chillán, Chile.

Catalá, R. 1998. Conservación de frutas y hortalizas en atmósfera controlada y modificada. Agroeconómico 45:15-19.

Ceponis, M., and R. Cappellini. 1985. Reducing decay in fresh blueberries with controlled atmosphere. HortScience 20:228-229.

Céspedes, C., C. Ovalle, y J. Hirzel. 2005. Manejo de la fertilidad del suelo en producción orgánica. Boletín $\mathrm{N}^{\mathrm{o}}$ 131. p. 25-63. Instituto de Investigaciones Agropecuarias (INIA), Chillán, Chile.

Granatstein, D. 2000. Alternative markets for fruit: Organic and integrated fruit protection. Proceedings of the 16th Annual Postharvest Conference, Washington, USA. 14-15 March. Available at http://postharvest. tfrec.wsu.edu/pgDisPlay.php? article $=$ PC2000M (accessed September 2008).

Gil, G. 2004. Fruticultura: madurez de la fruta y manejo poscosecha. Fruta de climas templado y subtropical y uva de vino. $2^{\text {a }}$ ed. Ediciones Universidad Católica de Chile, Santiago, Chile.

Gough, R.E. 1994. The highbush blueberry and its management. 272 p. Food Products Press, New York, USA. 
Hepp, R. 2005. Proyecto de investigación y desarrollo: Optimización en el manejo orgánico del arándano. In Seminario Internacional Cultivo del Arándano, La Serena, Chile. 13 abril 2005. Centro de Berries, Universidad de Concepción, Chillán, Chile.

Hevia, F., P. Lanuza, R. Wilckens, M. Tello, y D. Álvarez. 2000. Comportamiento de zarzaparrilla roja (Ribes rubrum) en almacenaje refrigerado y modificado. Agro Sur 28:42-50.

INN. 2004. Producción orgánica-Requisitos. NCh 2439 2004. Instituto Nacional de Normalización (INN), Santiago, Chile.

Kuepper, G., y S. Diver. 2004. Blueberries: Organic production. In Horticulture production guide. ATTRA Publication $\mathrm{N}^{\circ}$ IP021. p. 1-26. The National Center for Appropriate Technology (NCAT) Agriculture Specialist, Fayetteville, Arkansas, USA.

Little, T., y F. Hills. 1978. Métodos estadísticos para la investigación en la agricultura. Trillas, México D.F., México.

Loyola, N., y N. Andrade. 1993. Evolución del comportamiento de arándanos cv. Elliott en almacenaje refrigerado. Alimentos 18:55-57.

Loyola, N., M. Aranda, E. Teixidó, y H. Palma. 1996. Empleo de envases fisiológicos en frutos de arándanos para exportación. Agro Sur 24:113-125.

Loyola, N., M. Georgi, N. Andrade, y E. Teixidó. 1993. Comportamiento del arándano, mora cultivada, y mora silvestre en almacenamiento refrigerado y su impacto en la calidad. Agro Sur 21:59-69.

Makus, D., and J. Morris. 1987. Highbush vs. rabbiteye blueberry: A comparison of fruit quality. Arkansas Farm Research 36:5.

Miller, W., R. McDonald, and T. Crocker. 1988. Fruit quality of rabbiteye blueberries as influenced by weekly harvests, cultivars, and storage duration. HortScience 23:182-184.

Morales, K. 2004. Efecto de la incorporación de compost y cubiertas vivas anuales, sobre el crecimiento vegetativo del cerezo (Prunus avium L.), bajo un enfoque de producción orgánica, en la comuna de Lumaco, IX Región de La Araucanía. 70 p. Tesis de Ingeniero Agrónomo. Universidad Católica de Temuco, Facultad de Ciencias Agrarias y Forestales, Escuela de Agronomía, Temuco, Chile.
Navarrete, M. 2004. Arándano ojo de conejo (Vaccinium ashei Reade) cv. Bonita almacenado en atmósfera modificada. Tesis Ingeniero Agrónomo. Universidad de Concepción, Facultad de Agronomía, Chillán, Chile.

ProChile. 2003. El mercado de productos orgánicos en la Unión Europea, oportunidades y desafíos para Chile. ProChile, Santiago, Chile. Available at http://www. prochile.cl/registrar/autorizar.php?volver=www. prochile.cl\%2Fdoc.php\%3Ffile\%3Dorganicos_u europea_2003.pdf\&file=organicos_u_europea_2003. pdf (accessed 8 January 2006).

Romojaro, F., F. Riquelme, M. Pretil, G. Martínez, M. Serrano, C. Martínez, et al. 1996. Nuevas tecnologías de conservación de frutas y hortalizas: Atmósferas modificadas. Ediciones Mundi-Prensa, Madrid, España.

Sawyer, E., W. Kerr, and J. Hobbs. 2008. Consumer preferences and the international harmonization of organic standards. Food Policy 33:607-615.

Shea, K. 2004. Organic dairy production. Encyclopedia of Dairy Sciences 2193-2199.

Sinelli, N., A. Spinardi, V. Di Egidio, Ll. Mignani, and E. Casiraghi. 2008. Evaluation of quality and nutraceutical content of blueberries (Vaccinium corymbosum L.) by near and mid-infrared spectroscopy. Postharvest Biol. Technol. 50:31-36.

Smith, E., and T. Marsden. 2004. Exploring the limits to growth in UK organics: Beyond the statistical image. J. Rural Stud. 20:345-357.

Smittle, D., and W. Miller. 1988. Rabbiteye blueberry storage life and fruit quality in controlled atmospheres and air storage. J. Amer. Soc. Hort. Sci. 113:723-728.

StatSoft. 1996. Statistica. Versión 6.0. StatSoft, Tulsa, Oklahoma, USA.

Watkins, C., and J. Zhang. 1998. Metabolic responses of fruit to carbon dioxide. Acta Hort. (ISHS) 464:345350 .

Wiley, R. 1997. Frutas y hortalizas mínimamente procesadas y refrigeradas. Acribia, Zaragoza, España.

Wills, R., B. McGlasson, D. Graham, and D. Joyce. 1998. Postharvest. An introduction to the physiology and handling of fruit, vegetables and ornamentals. $4^{\text {th }} \mathrm{ed}$. 262 p. Hyde Park Press, Adelaide, Australia. 